\title{
A Behavioral Approach To Derive The Cost Of Equity Capital For Small Closely Held Firms
}

Denis Boudreaux, (E-mail: Dob0896@louisiana.edu), University of Louisiana, Lafayette Tom Watson, (E-mail: Ok370@excite.com), University of Louisiana, Lafayette

James Hopper, (E-mail: Jhopper987@aol.com), University of Louisiana, Lafayette

\begin{abstract}
The purpose of this research is to explore the theoretical structure that underlies the valuation process for small closely held firms. All discounted cash flow valuation models require an estimate of a firm's weighted average cost of capital as well as the firm's component cost of equity capital. The CAPM is frequently employed to measure the cost of equity capital for a publicly traded firm. A publicly held firm's common stock price is determined in the capital markets and is readily available. The firm's stock price can then be used to estimate its beta; a necessary input to the CAPM. Because there is no information about stock prices, the task of estimating the cost of equity for a closely held firm is more challenging. The build-up model is frequently used to calculate the cost of equity for the closely held firm. However there is much controversy over this model's assumptions, reliability and validity. Specifically, this research critiques the build-up model identifying its advantages and its liabilities. The purpose of this work is to create discussion and stimulate economists to study and improve this important area. Additionally, this study offers a new economic model to estimate the cost of equity capital that is theoretically correct easy to understand
\end{abstract}

\section{INTRODUCTION}

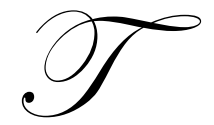

he purpose of this work is to explore the theoretical structure that underlies the valuation process for closely held businesses. Most valuation methods employ a discounted cash flow methodology. The models generally rely on predictions of cash flow and cost of capital estimates, tasks that may be quite complex when applied to small closely held firms. This research effort will critique the most frequent cost of capital assessment method that appears in the current literature and used by many practitioners: the build-up model. The build-up model is conceptually simple and implicitly pleasing.

\section{COST OF CAPITAL}

The estimate of the cost of capital for a closely held company is required for several important reasons. Whenever the value of the firm must be determined, the cost of capital must be estimated. Required valuation can arise out of litigation involving the owners of a firm and its employees, competitors, suppliers, the government or other stakeholders. Litigation necessitating the valuation of closely held firms typically stems from disputes that range from divorce settlements, business dissolutions, estate taxation issues, to those involving business damages such as dissenting stockholder suits, lost business opportunities, breach of contract, antitrust actions, personal injury and insurance property or casualty claims. Governmental agencies may also condemn or seize business property through eminent domain or appropriation proceedings. In each situation, the value of the firm and its cost of capital for at least one particular point in time must be determined.

The closely held company's management must estimate its firm's cost of capital for capital budgeting analysis. Capital budgeting is very similar to valuing the firm except you are valuing a single project. The capital budgeting selections are the most important decisions management makes. These decisions determine the future cash 
flows and risk of the firm. The most theoretically correct capital budgeting method, the Net Present Value Method (NPV), discounts the expected cash flows by the firm's cost of capital. The Internal Rate of Return for a capital investment is compare to the firm's cost of capital as a hurdle rate to determine feasibility.

The Discounted Cash Flow Model to value a business (same as the NPV model for capital budgeting) is stated below.

$\mathrm{V}_{\mathrm{B}} \quad=\mathrm{SUMCF}_{\mathrm{Bt}} /(1+\mathrm{k})^{\mathrm{t}}$

Where:

$\mathrm{V}_{\mathrm{B}} \quad=$ value of firm $\mathrm{B}$,

$\mathrm{CF}_{\mathrm{Bt}}=$ the estimated firm cash flow for year $t$,

$\mathrm{k}=$ the cost of capital.

\section{DIFFERENCES IN VALUATION OF CLOSELY HELD BUSINESSES AND PUBLICLY TRADED FIRMS}

Differences between closely held firms and publicly traded corporations influence valuation methodology. For example, publicly held firms are required to have their financial statements annually audited by certified public accountants, and these statements also are made available to the public. Closely held firms do not have this requirement. Since financial statements are vital in determining expected cash flows, the cost of capital and the worth or value of the firm, an expert may have to review unaudited financial statements of closely held firms with greater caution. Another key difference in publicly held versus closely held firms has to do with the reality that the cash flows available to owners of closely held firms typically encompass more than mere declared dividends. Such additional flows include salary or other direct remuneration and indirect compensation or perks. Other typical benefits include that which may accrue from control over depreciation assets such as the use of business vehicles or similar expense recognition such as business trips and various other types of accounting and/or tax benefits.

An important part of the valuation process is the determination of the discount rate to be used in estimating the present value of the cash flow stream. This discount rate is the required rate of return for the primary stakeholders of the firm. For any firm, this would be the weighted average cost of capital, which is estimated from the marginal after-tax costs of debt, preferred stock, and common stock. The cost of capital for a publicly traded firm is the result of arms-length transactions that are empirically observable. For the publicly held firm, because stock and bond prices are market determined and publicly available, the cost of capital can easily be estimated. These financial transactions are required to be disclosed as public information, whereas closely held firms are under no such obligation. Thus, derivation of an appropriate cost of capital measure is much more difficult for closely held firms than for publicly traded firms. The components of the applicable cost of capital also differ by type of ownership. First, the cost of debt financing for a closely held firm is usually different (higher) than for a comparable publicly held firm. Closely held firms generally must rely on trade credit and loans or lines of credit from owners and financial institutions such as commercial banks, whereas publicly traded companies may issue more cost effective corporate bonds as well. Even though debt costs are generally higher for the small closely held firm, these costs can be estimated by reviewing the firm's loan interest rates and its marginal tax rate. If the firm has historically been granted loans at prime, then its current rate at the margin is the present prime rate. Second, the costs of equity also differ for publicly held and closely held firms. For example, investments in publicly held firms generally impose less liquidity risk to owners than do closely held firms. The relative marketability or ease with which an owner may sell their stake in a firm impacts the cost of equity, required returns, and valuation. All things being equal, an interest in a business is worth more if it is readily marketable. Interests in closely held businesses are not liquid relative to most other investments. In valuation cases of closely held firms, both the Internal Revenue Service (see, in particular, Revenue Ruling 59-60) and the courts have consistently recognized that a higher discount rate should be applied to account for the lack of marketability.

An important but related issue pertains to the degree of control the ownership interest has in the firm. The issue of control is often of prime concern in valuations of small or closely held firms. A trade of a small portion of 
the small firm's stock may result in a significant change in control in contrast to that of publicly traded firms. All things being equal, an interest in a business may be worth more if it represents a controlling (majority) interest. Contrary to any fiduciary duty majority owners may owe, holders of a minority interest may be unjustly subjected to policies or practices that may limit the value of their minority position (e.g., excessive salary or compensation for majority owner/managers), and jurisdictions differ in the establishment of rights, privileges and protections afforded minority interest holders. The increase in discount rate attributable to the lack of marketability, in conjunction with the compound problem associated with a minority interest, may be a most difficult issue to resolve. Differences in equity cost and required returns also may result from portfolio effects that stem from the investment holdings of firm owners. Publicly traded firms are generally owned by investors whose loss is limited to the market value of the shares held. Investors holding well diversified portfolios face a lower level of total risk, and variability in returns, because such diversification reduces the relative impact of company-specific (i.e., unsystematic) risk in their total portfolio of investments. By contrast, owners of closely held firms are quite poorly diversified, as the bulk of their personal wealth, effort and self-worth may are usually tied up in their firm. Without the benefit of a reduction in unsystematic risk that accrues to properly diversified investors, the primary risk facing owners of small firms is the relative variability in returns for that individual firm. Therefore, owners of closely held firms often bear greater total risk, and may have higher potential return expectations, than owners or shareholders of publicly held firms. However, some of these increased expectations may be more easily satisfied by benefits that may be considered somewhat non-economic in nature (e.g., need for prestige or community standing, among others).

\section{THE BUILD-UP MODEL}

The build-up approach breaks down the cost of equity capital into different components and specifies a percentage for each component. Build-up models generally begin with a risk-free rate and add one or many factors based on the risk of the equity instrument. Some of the more common components used In this approach include:

1. risk-free rate

2. equity risk premium

3. size premium

4. $\quad$ specific company premium

5. country risk premium

This approach can be expressed as the following model:

$\mathrm{Ke}=\mathrm{Rf}+\mathrm{RPm}+\mathrm{RPs}+\mathrm{RPu}+\mathrm{Rpi}$

Where:

$\mathrm{Ke}=$ expected equity return or cost of equity capital

$\mathrm{Rf}=$ risk-free rate

$\mathrm{RPm}=$ equity risk premium for market (general market equity risk premium)

RPs $=$ size premium

$\mathrm{Rpu}=$ specific company premium (u stands for unsystematic risk)

Rpi = country risk premium (international investing).

The risk-free rate (Rf) is usually proxied by the current yield on the twenty-year US Treasury bonds. This rate is empirically observable. To estimate the market risk premium (RPm), historical yields or Ex post methods are commonly employed. Ibbotson Associates publishes historical risk premium data in its annual Stocks, Bonds Bills and Inflation as well as Cost of Capital. This is a source that is often used as the estimate for equity risk premium in the build-up method. Recent studies have provided evidence that the degree of risk and the corresponding cost of capital increase with the decreasing size of the company. The size premium (RPs) is to capture this higher risk and cost. There are no adequate empirical studies to quantify this higher cost for small non-publicly traded firms. Ibbotson Associates attempts to quantify the higher cost of capital for the firms listed on the New York Stock Exchange (NYSE) by industry in its Cost of Capital, Quarterly. However, in some records the yields for the smaller 
firms are larger than the bigger firms, causing theoretical conflicts. Ibbotson also reports the excess annual returns for the smallest firms listed on the NYSE over the largest firms' returns (SBBI Valuation Edition). These higher returns are reported for various size companies broken down into 10 deciles and decile 10 is broken down again into 2 deciles. This size premium is the return in excess of the Capital Asset Pricing Model. These excess returns are estimated by capturing the actual returns of the small firms combined into a portfolio over time. This portfolio does not properly reflect firms that have been dropped from the exchanges because of delisting or failure and overestimate the true returns of a portfolio of small publicly held firms. Accordingly, the size premium is mostly a subjective assignment based on an expert's experience and personal observations. The specific company premium (Rpu) encompass risk relating to the industry in which the company operates; higher or lower company return volatility; leverage differences; dependencies on key customers, suppliers, or employees; lawsuits; and other unsystematic risk factors. The size premium tends to capture most of the unsystematic risk and this adjustment should be for only very unique company factors. This premium is not quantified by research so it must be subjectively estimated.

\section{RESULTS OF BUILD-UP MODELS}

Forensic economists in damage cases, especially working for the defense frequently use the build-up model to estimate the firm's cost of equity. Their estimates of the equity cost of capital frequently exceed 28 percent and can be as high as 40 percent. For example, the expert will start with a Risk Free Rate of 4.8 percent (20 year T-Bond rate), add the equity risk premium of 7 percent (Ibbotson), add the small firm risk premium of 9.16 percent (Ibbotson), add an industry premium of 2.9 percent (Ibbotson Industry Premia Estimates), and then add company risk premiums such as economic slow: 2 percent, Key man: 1 percent and competition: 2 percent for a total required return of 28.86 percent. The expert could have included addition risk premiums for location, concentrated customer base, etc. to get even a higher desired high estimate. The economist then uses this rate minus a minimal growth rate (sustainable) to determine the capitalization rate. The last step is to estimate the base rate of earnings (free cash flow) and capitalize the flow to find the firm's value. Although the economist is using a huge required return that should reflect the uncertainty in the expected cash flows and their growth rate, the expert representing the defense will use very conservative free cash flow and growth estimates biasing the results. A low-end annual free cash flow of $\$ 250,000$ with a cost of equity capital estimate of 28.86 percent with a 1 percent growth rate (27.86 capitalization rate) yields a value of only $\$ 897,344$. Reversing this analysis, a simple annuity (no growth rate) of $\$ 250,000$ at 27.86 percent for 50 years is worth $\$ 193,928,700,000$. Is it conceivable that a firm is valued at less than 1 million dollars will be worth almost 200 billion in only 50 years? Is it believable that the current firms in the U.S. that have a free cash flow of $\$ 250,000$ will achieve a market value of 193 billion in 50 years? How many firms are actually going to achieve such results?

\section{THE UTILITY APPROACH TO MEASURE THE SMALL FIRM'S EQUITY COST OF CAPITAL}

Investors derive utility from owning and controlling their firm and from the liquidity of the firm's worth. While a utility approach is not common in investment analysis, it may be the best starting point given the lack of market signals on closely held firms. The market for publicly traded firms provides an idea of the opportunity costs to invest in a non-traded firm. Further the fact that some continue to expose themselves to elevated risk after the increased return on their investment is clearly not attainable suggests some intangible attraction.

Assume there are two types of investments: closely held firms (controllable) and the publicly traded small firms (liquid). The real returns on these firms are normalized for the level of risk. Little work has been done from this approach, thus a theoretically and mathematically simple function should be used as a starting point. Assume the investor has a standard Cobb-Douglas utility function of:

$U=C^{a} L^{B}$

Where:

$\mathrm{C}=$ investment in closely held firms,

$\mathrm{L}=$ investment in publicly traded firms, and 
$\mathrm{a}+\mathrm{B}=1$

This particular function is robust and posses all of the mathematical features to be easily estimated using regression analysis. The investor seeks to maximize his utility subject to the constraint:

$\underline{P}=\underline{C}+\underline{L}$

$\begin{array}{lll}r_{p} & r_{c} & r_{L}\end{array}$

Where

$r_{p}=$ real rate of return on the entire portfolio,

$r_{c}=$ the real rate of return on the closely held firms, and

$\mathrm{P}=$ the total portfolio budget

The terms are divided by the real rate of return to capture the inverse relationship between the prices of the stocks and the returns. The earnings are normalized so the model can be evaluated.

Working out the first order conditions for the constrained optimization, the following is true:

$\underline{a L}=\underline{r_{c}}$

$B C r_{L}$

The real rate of return on publicly traded shares can be observed in the market. The ratio of closely held firms to publicly held firms (dollar value of closely held/dollar value public) can be observed in various investors' portfolios. Only assumptions about $\square$ and $\square$ need to be made. The term $\square$ represents the portion of utility provided by the closely held investment. The term $\square$ represents the portion utility provided by the publicly traded firm. This provides the basis for assumptions. We can assume that many investors enjoy the control of closely held firms based on their level of investment in these firms. Many investors in small business have a large portion of their time and wealth tied up in their small closely held firms. Their level of involvement suggests that the firm is a source of income for the investor; therefore it can represent the utility involved with the consumption of all other goods. Further, managing a private firm can provide some level of utility above that involved in simply consuming the investment income from more liquid investments. These factors lead to assumption that $\square$ is significantly larger that $\beta$. Once the ratio is rearranged and descriptive statistics are attained for the portfolio analysis of the small business investors.

\section{METHODOLOGY}

A survey of 50 small business investors was used to develop the economic model. Information concerning the owners' investment in the firm as well as holdings in publicly traded instruments was analyzed to generate the data set. The model depends on information about the ratio of $\alpha$ to $\beta$, which is not directly estimable from the data gathered. Several runs of the data were performed using various assumptions about the ratio. The best assumption of this ratio is based on the fact that most small business investors obtain their normal income from the business. The utility derived from the investment in the small firm represents that which they gain from the consumption of all other goods. Further they receive direct utility from the intangible factors involved with owning their own business, such as control of time, prestige, and use of the business assets for personal reasons. Therefore it is reasonable to assume the value $\alpha$ is much larger than $\beta$. A simple value that matches this assumption is 9 . The ratio of 9:1 simply states $90 \%$ of the utility is from the closely held investment, supporting the assertion that most of the income is from the closely held firm.

\section{RESULTS}

Using a ratio of 9 , the average required return was $20.98 \%$ with a standard error of $14.44 \%$. The results of the model are intended to illustrate the return on equity investment required to keep the small, closely held business 
owner satisfied with his investment. The results compare favorably to the numbers provided by the business owners as their target returns in the survey, which averaged $19 \%$ with a range of $12 \%$ to $40 \%$, with a standard error of $7.2 \%$.

\section{CONCLUSION}

The primary advantages of the build-up model are simplicity and conceptualization. This method offers the appeal of logic to courts and non-experts. A small closely held firm should probably have a high cost of equity capital. Also, many of the components are derived from actual, albeit historic, data. This method may be more accurate when applied to very large American companies as many of the factors will not be included in the model (e.g. size premium, specific company premium, country risk premium), reducing the chance for error. The major problems associated with applying these methods to small, closely held firms are that the expert has little hard evidence to specifically quantify many of the subjective components. Also, the different components are not perfectly separable and this makes the premiums also not separable. Similar to the nominal rate on a commercial bond, the interest rate cannot be broken down with great confidence and precision into a real interest rate, an inflation premium and the multiple components of the risk premium. Corporate bond yields are much less convoluted than required equity returns for small non-publicly held companies. The build-up model is not robust and cannot be used in a truly scientific way for small firms. Therefore, the solution to the cost of capital equation using the build-up model is not precise and therefore not reliable under Daubert standards.

The results of the behavioral approach are encouraging and invite further study. A more thorough study of small business investors is required, and further development of the function used in developing the figures will lend to the acceptance of this method. For more thorough studies the survey should be broken into industry specific areas, and it should distinguish between controlling ownership and passive equity holdings. Firm size and age will have an effect on the cost of equity capital due to various factors, and these variables can be easily incorporated into the model. The study provides strong support for future research in a broader range of variables to determine the cost of capital for all nonpublic corporations.

\section{REFERENCES}

1. $\quad$ Cost of Capital Quarterly; 1998 Yearbook. Ibbotson Associates. Chicago, IL.

2. Benore, Charles. Paine Weber Reports, various issues.

3. Boudreaux, Philip A. 1995. Culver II and the Below-Market Discount Rate: A Case for Judicial Review, Journal of Business and Economic Perspectives 21 (Spring): 20-25.

4. Boudreaux, Denis O. and Philip Boudreaux. 2002. Using The DCF Model to Measure Bond Risk Premiums, Working paper.

5. Gitman, Lawrence J. 1994. Principles of Managerial Finance (7th ed.). New York: Harper Collins.

6. Internal Revenue Service. 1959. Revenue Ruling 59-60, 1959-1, C.B. 237.

7. Peterson, Renno L. 1989. A Guide to Valuing the Closely Held Business. The Practical Accountant (April): 34-50.

8. Pratt, Shannon P. 1993. Valuing Small Businesses and Professional Practices (2nd ed.). Homewood, IL: Business One Irwin.

9. $\quad$ Pratt, Shannon P. 1998. Cost of Capital: Estimation and Applications. New York: Wiley.

10. Pratt, Shannon P., Robert F. Reilly, and Robert P. Schweihs. 1996. Valuing a Business: The Analysis and Appraisal of Closely Held Companies (3rd ed.). Chicago: Irwin Professional Publishing.

11. Robichek, Alexander A. and Stewart C. Myers. 1966. Conceptual Problems in the Use of Risk-Adjusted Discount Rates. Journal of Finance (December): 727-730.

12. Van Horn, James C. 1995. Financial Management and Policy (10th ed.). Englewood Cliffs: Prentice Hall.

13. Weston, J. Fred, and Thomas E. Copeland. 1992. Managerial Finance (9th ed.). Orlando: Dryden Press.

14. Zukin, James H., ed. 1990. Financial Valuation: Businesses and Business Interests (with 1998 Cumulative Index). New York: Warren Gorham \& Lamont/RIA Group. 